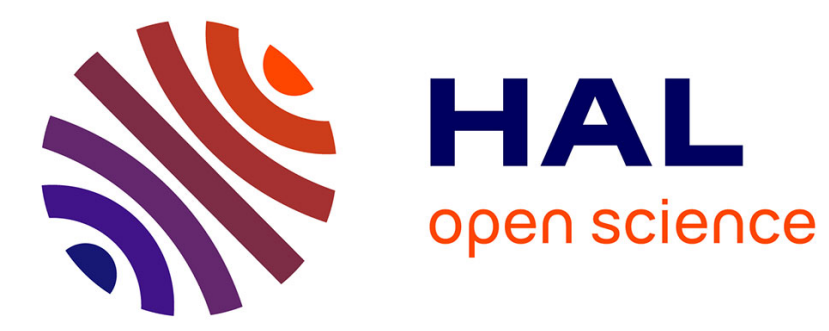

\title{
Impact of Swiss agricultural policies on nitrate leaching from arable land
}

\author{
M. Decrem, E. Spiess, W. Richner, F. Herzog
}

\section{To cite this version:}

M. Decrem, E. Spiess, W. Richner, F. Herzog. Impact of Swiss agricultural policies on nitrate leaching from arable land. Agronomy for Sustainable Development, 2007, 27 (3), pp.243-253. hal-00886373

\section{HAL Id: hal-00886373 \\ https://hal.science/hal-00886373}

Submitted on 1 Jan 2007

HAL is a multi-disciplinary open access archive for the deposit and dissemination of scientific research documents, whether they are published or not. The documents may come from teaching and research institutions in France or abroad, or from public or private research centers.
L'archive ouverte pluridisciplinaire HAL, est destinée au dépôt et à la diffusion de documents scientifiques de niveau recherche, publiés ou non, émanant des établissements d'enseignement et de recherche français ou étrangers, des laboratoires publics ou privés. 


\title{
Impact of Swiss agricultural policies on nitrate leaching from arable land
}

\author{
M. DECREM, E. SPIESS*, W. RICHNER, F. HERZOG \\ Agroscope Reckenholz-Tänikon Research Station ART, Reckenholzstrasse 191, 8046 Zurich, Switzerland
}

(Accepted 5 March 2007)

\begin{abstract}
From 1993 onwards, various policy measures aiming at reducing nitrogen (N) losses were introduced in Swiss agriculture. We studied the impact of these measures on nitrate leaching under arable land in the Fehraltorf catchment near Zurich. Because of the well-drained soils, the shallow water table and the intensive agricultural activity, the groundwater in this catchment is highly vulnerable to nitrate pollution. $\mathrm{N}$ fluxes and transformations on the field scale were simulated using the deterministic model LEACHMN. Following the calibration of the model with a dataset from a long-term lysimeter experiment, simulations were run for the period 1998-2003. As far as possible, field-specific management data from farmers' control sheets were used as input. Average nitrate leaching in the period 1998-2003 was estimated to amount to $39 \mathrm{~kg} \mathrm{~N} \mathrm{ha}^{-1}$ year $^{-1}$. The conditions before the introduction of the policy measures were simulated in three scenarios with a higher use of both mineral $\mathrm{N}$ fertiliser and animal manure and 50\% less or no catch crops. We found that lowering mineral $\mathrm{N}$ fertiliser and manure application by about $25 \%$ led to an average decrease in nitrate leaching of $10 \mathrm{~kg} \mathrm{~N} \mathrm{ha}^{-1}$ year $^{-1}$. Doubling the catch crop area yielded a further decrease of $6 \mathrm{~kg} \mathrm{~N} \mathrm{ha}^{-1}$ year $^{-1}$ on average. Altogether, the implementation of reduced $\mathrm{N}$ fertiliser inputs and increased use of catch crops proved to be effective and led to a mean reduction in $\mathrm{N}$ leaching of $29 \%\left(16 \mathrm{~kg} \mathrm{ha}^{-1} \mathrm{year}^{-1}\right)$ for the arable land in the Fehraltorf catchment.
\end{abstract}

cross-compliance / groundwater pollution / LEACHMN / nitrate / nitrogen / non-point source pollution

\section{INTRODUCTION}

In Switzerland, groundwater still exceeds official limits for nitrate in drinking water in many wells (BUWAL and BWG, 2004). Nitrate leaching from agricultural land also contributes substantially to excessive $\mathrm{N}$ loads into the river Rhine, leading to eutrophication in the North Sea (Prasuhn and Sieber, 2005). In the early 1990s, increased awareness of environmental damage caused by agriculture and growing costs for the regulation of agricultural markets led to the introduction of agri-environmental programmes in a number of countries in Europe, including Switzerland (e.g. Herzog, 2005). From 1993 onwards, following an animated public debate, the Swiss agricultural policy was reframed. At first, incentives were given to farmers to convert their farming practices towards integrated production methods. In 1996, a public vote on the article about agriculture in the Swiss constitution confirmed this policy and led to the implementation of a cross-compliance system enacted in the Swiss constitution. It implies that farmers, in order to qualify for direct payments, have to meet the requirements of the "Proof of ecological performance" programme (Conseil Fédéral, 1998). A similar process is presently under way in the countries of the European Union, with the introduction of a new system of support, the "Single Farming Payment", which is no longer linked to production but to compliance with environmental regulations and standards.

The ecological requirements of the "Proof of ecological performance" (Conseil Fédéral, 1998) stipulate that the farms'

* Corresponding author: ernst.spiess@art.admin.ch nitrogen $(\mathrm{N})$ and phosphorus $(\mathrm{P})$ budgets need to be equilibrated, i.e. $\mathrm{N}$ and $\mathrm{P}$ input may not exceed crop demand by more than $10 \%$. Moreover, bare soil in winter is to be minimised. These two requirements aim at a reduction of nutrient and soil losses in order to prevent water pollution. Other measures with respect to pesticides, habitats and animal husbandry target water quality as well, but also biodiversity and animal welfare. In 2005, 97\% of the utilised agricultural area of Switzerland, including organic farming, was farmed under the regulations of the "Proof of ecological performance" (OFAG, 2006). In general, the use of $\mathrm{N}$ fertilisers (mineral $\mathrm{N}$ fertilisers and livestock manure) has decreased to meet the requirements of the "Proof of ecological performance". The Swiss average consumption of mineral $\mathrm{N}$ fertilisers per hectare of agricultural land, which had doubled between 1975 and 1988, decreased by c. $25 \%$ during the 1990 s (Spiess, 2005).

Models have become increasingly employed in the evaluation of policy measures for the reduction of $\mathrm{N}$ losses to ground- and surface waters caused by agricultural activities (Wendland et al., 1998; Granlund et al., 2000; Børgesen et al., 2001; Müller-Wohlfeil et al., 2002; Chaplot et al., 2004; Fassio et al., 2005; Wolf et al., 2005 and others). By only varying the measures that are of interest in the context of policy evaluation whilst keeping all other factors that affect the water and $\mathrm{N}$ balance in agro-ecosystems constant (namely, variations in temperature and precipitation), models can provide indications about the effectiveness of individual measures. Two types of models are usually considered for such policy evaluations: empirical and deterministic models. Empirical models are best suited for broad, large-scale investigations of general 


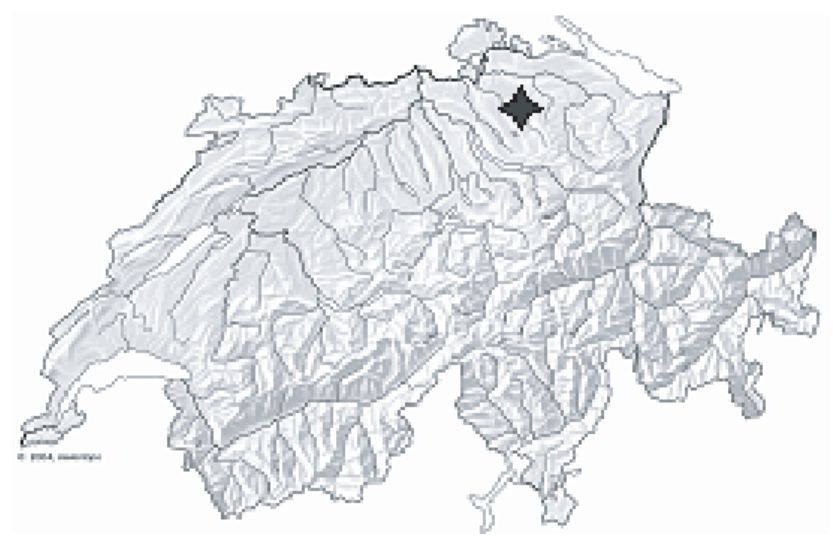

(a)

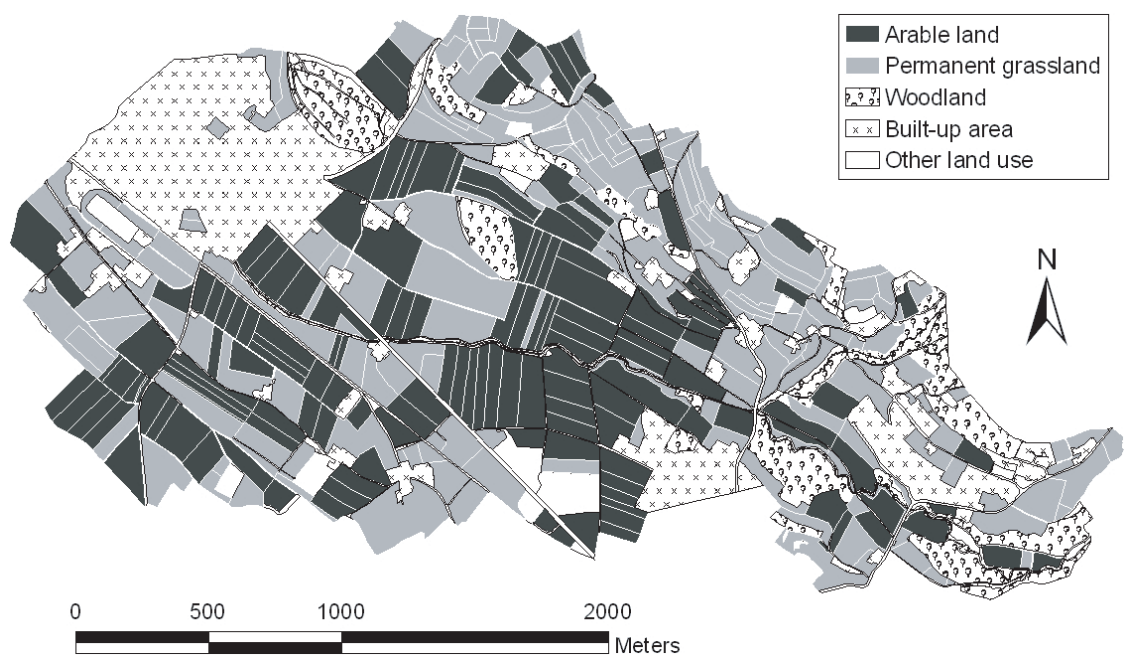

(b)

Figure 1. Location and general features of the Fehraltorf catchment.

patterns of $\mathrm{N}$ fluxes in agro-ecosystems. By contrast, deterministic models are, in theory, of more general applicability, as they include a mechanistic description of the processes. These models are quite complex and are associated with large data requirements. They can be used for more detailed, small-scale investigations, where subtle differences between management regimes are the focus of interest. For an overview of state-ofthe-art $\mathrm{N}$ emission models, including $\mathrm{N}$ leaching models, see Wolf et al. (2005). The decision of whether to use empirical or deterministic models depends on the availability of expertise (to parameterise an empirical model), of data (to drive a deterministic model) and of the precise questions asked.

The objective of this study was to assess whether the reduction in $\mathrm{N}$ fertiliser input and the increase in catch crop use, which are both part of the requirements of the "Proof of ecological performance", did actually lead to a reduction of $\mathrm{N}$ leaching from arable land. Whereas the status of groundwater quality is monitored on the national scale (BUWAL and BWG, 2004), the results of these monitoring programmes do not inform about the effectiveness of individual policy measures, as water quality is affected by a wide range of factors inside and outside the agricultural sector. These complex relationships can only be explored with the aid of model scenarios. Because we aimed at investigating rather subtle differences in management (nitrogen fertilisation levels and catch cropping), we had to use a deterministic rather than an empirical model and, as a consequence, we had to limit the study to a small catchment, for which it was actually feasible to gather the necessary input data.

The study was embedded in a comprehensive programme evaluating the effectiveness of the Swiss "Proof of ecological performance" (Herzog and Richner, 2005).

\section{MATERIALS AND METHODS}

\subsection{Description of the catchment and agricultural management practices}

We conducted our study in the catchment of 'Fehraltorf' (Fig. 1), which is located $30 \mathrm{~km}$ east of Zurich in the Plateau region of Switzerland. The catchment covers approximately 540 ha. The landscape was formed by glaciers during the last 
Table I. Mean textural composition, areal fraction and available water content (for a 1-metre profile) of the soil types in the arable land of the Fehraltorf catchment.

\begin{tabular}{|c|c|c|c|c|c|c|c|c|}
\hline \multirow{2}{*}{$\begin{array}{l}\text { Soil type (Swiss } \\
\text { classification system) }\end{array}$} & \multirow{2}{*}{$\begin{array}{l}\text { Soil texture } \\
\text { class } \\
\text { (USDA) }\end{array}$} & \multicolumn{3}{|c|}{ Mean textural composition } & \multirow{2}{*}{$\begin{array}{l}\text { Organic } \\
\text { matter } \\
(\%)\end{array}$} & \multirow{2}{*}{$\begin{array}{l}\text { Coarse material } \\
(>2000 \mu \mathrm{m}) \\
(\% \text { by volume }) \\
(\%)\end{array}$} & \multirow{2}{*}{$\begin{array}{l}\text { Fraction of the } \\
\text { total arable area } \\
\text { in the catchment }\end{array}$} & \multirow{2}{*}{$\begin{array}{l}\text { Available } \\
\text { water content }^{1} \\
(\mathrm{~mm})\end{array}$} \\
\hline & & $\begin{array}{l}\text { Clay } \\
(0-2 \mu \mathrm{m}) \\
(\%)\end{array}$ & $\begin{array}{l}\text { Silt } \\
(2-60 \mu \mathrm{m}) \\
(\%)\end{array}$ & $\begin{array}{l}\text { Sand } \\
(60-2000 \mu \mathrm{m}) \\
(\%)\end{array}$ & & & & \\
\hline Brown soil & Loam & 23 & 31 & 46 & 3.1 & 5 & 8.8 & 220 \\
\hline$"$ & $"$ & $"$ & $"$ & $"$ & $"$ & 15 & 17.5 & 199 \\
\hline$"$ & $"$ & $"$ & $"$ & $"$ & $"$ & 20 & 7.9 & 189 \\
\hline Calcaric brown soil & Loam & 24 & 30 & 46 & 3.3 & 15 & 1.2 & 209 \\
\hline$"$ & $"$ & $"$ & $"$ & $"$ & $"$ & 20 & 1.1 & 198 \\
\hline$"$ & $"$ & $"$ & $"$ & $"$ & $"$ & 35 & 0.7 & 166 \\
\hline Gley brown soil & Loam & 27 & 32 & 41 & 4.6 & 5 & 1.3 & 186 \\
\hline$"$ & $"$ & $"$ & $"$ & $"$ & $"$ & 10 & 0.6 & 177 \\
\hline$"$ & $"$ & $"$ & $"$ & $"$ & $"$ & 20 & 4.1 & 157 \\
\hline Para brown soil & Loam & 19 & 31 & 50 & 2.7 & 15 & 1.7 & 221 \\
\hline$"$ & $"$ & $"$ & $"$ & $"$ & $"$ & 20 & 34.8 & 211 \\
\hline$"$ & $"$ & $"$ & $"$ & $"$ & $"$ & 30 & 14.5 & 190 \\
\hline Oxidised gley & Clay Loam & 32 & 33 & 36 & 5.9 & 20 & 1.8 & 181 \\
\hline Reduced gley & Clay Loam & 29 & 31 & 40 & 12.5 & 5 & 3.0 & 217 \\
\hline Regosol & Loam & 22 & 29 & 48 & 3.6 & 20 & 1.1 & 207 \\
\hline
\end{tabular}

${ }^{1}$ Calculated as difference in moisture content between field capacity and permanent wilting point.

ice age and is gently undulating with elevations that range from 530 to $650 \mathrm{~m}$ above sea level. Flat, open land characterises the southern part of the catchment, whereas steeper slopes (up to $15 \%$ ) characterise the northern upper part. Land use was mapped by interpretation of aerial photographs taken in August 2000 and information from the farmers. The main land use is agriculture (68\%), which is divided into arable land (28\%) and grassland (40\%). Forested areas cover $9 \%$ of the catchment; the rest includes, among others, an urbanised area. 158 arable parcels are shared among 29 farms.

The climate of the region is humid temperate, with an average yearly precipitation of $1400 \mathrm{~mm}$ for the study period (1998-2003) and an average yearly air temperature of $9.9^{\circ} \mathrm{C}$. Daily precipitation data were measured from a meteorological station situated near the catchment. Other standard daily meteorological variables used as inputs to the model (air temperature, humidity, global radiation and wind speed) were collected at Agroscope Reckenholz-Tänikon Research Station ART, Zurich. The observation period includes a wet year, i.e. $1998 / 99$ with an annual precipitation of $1625 \mathrm{~mm} \mathrm{year}^{-1}$, and a rather dry year, i.e. 2002/03 with $1155 \mathrm{~mm} \mathrm{year}^{-1}$.

Information on soils was derived from the 1:5000 soil survey map and database of Canton Zurich (VDZH, 1998). Seven different soil types were identified for arable land in the catchment (Tab. I). The brown soils (Cambisols) and para-brown soils (Luvisols), characterised by a loamy texture and a mod- erate percentage of coarse fragments, are the dominating soil types ( $80 \%$ of the arable land). Further information provided by farmers indicated that $<4 \%$ of the arable area were artificially drained.

\subsection{The LEACHMN model}

The study was conducted with LEACHMN, which is a quantitative deterministic model that simulates the $\mathrm{N}$ fluxes and transformations on the field-plot scale, assuming onedimensional, vertical transfer of water and solutes through the soil (Hutson and Wagenet, 1991; Hutson, 2003). LEACHMN was chosen because it has been evaluated in several model simulation studies (Jemison et al., 1994; Jabro et al., 1995; $\mathrm{Ng}$ et al., 2000; Sogbedji et al., 2001a,b), and was found to provide reasonably accurate predictions of $\mathrm{N}$ leaching losses. Its parent model is SOILN (Johnsson et al., 1987), a model whose performances under temperate conditions are well documented. The rationale for choosing LEACHMN over SOILN is the way in which water and solute transport is calculated: the Jan. 2003 revised version of LEACHMN includes a form of the capacity ('tipping-bucket') approach, which is assumed to be less affected by the interaction between non-linearity of the model and spatial variability of soil parameters, in comparison with the Richards' equation approach used in SOILN (Addiscott and Mirza, 1998). 
LEACHMN takes into account the main sources (mineral and organic fertilisation, incorporation of crop residues, and atmospheric deposition), sinks (removal of harvest products, leaching, surface runoff, sorption to the soil matrix, volatilisation and denitrification) and transformations (mineralisation, nitrification and immobilisation) of the $\mathrm{N}$ cycle in the root zone of field crops. In the base version of LEACHMN, the simulation of $\mathrm{N}$ mineralisation considers two different types of organic pools: the fast-cycling organic $\mathrm{N}$ pools, associated with crop residues and faeces from manure, and the 'stable' organic N pool, associated with the soil humus. We slightly altered the model structure in order to facilitate the parameterisation of manure turnover using data on plant-available $\mathrm{N}$. In the modified version, organic $\mathrm{N}$ associated with soil humus was divided into active and inactive pools. The inactive humus $\mathrm{N}$ pool received the fraction of manure organic $\mathrm{N}$ regarded as slow cycling, i.e. unavailable to crops in the short to medium term (2-3 years).

Plant uptake of $\mathrm{N}$ is estimated using a supply and demand approach. The potential $\mathrm{N}$ uptake is computed on a daily basis from the 'target' total plant $\mathrm{N}$ uptake, which is specified as input to the model. If the amount of nitrate and ammonium $\mathrm{N}$ in the root zone is insufficient for the potential $\mathrm{N}$ uptake, the simulated $\mathrm{N}$ uptake will be reduced proportionally and the target $\mathrm{N}$ uptake will not be attained at harvest time. An adaptation of the model was required for dealing with autumn-sown annual crops, because the original version of LEACHMN can only handle spring-sown annual crops. Basically, in the approach we used, a winter-sown crop was figured as equivalent to a succession of two virtual crops, the first growing from the time of seeding until early December (pre-dormancy) and the second growing from early March until harvesting (post-dormancy).

Preferential flow through cracks and macropores, artificial drainage, effects of snow cover and soil freezing/thawing, and (in the 'tipping-bucket' approach used in this study) upward flow of groundwater towards the soil surface ('capillary rise') are not taken into account by the model. Because it does not describe the process of symbiotic $\mathrm{N}$ fixation, LEACHMN is not well suited for investigation of $\mathrm{N}$ cycling in grassland systems where symbiotic $\mathrm{N}$ fixation is an important component of the overall $\mathrm{N}$ balance.

\subsection{Application of the model}

LEACHMN was applied on the basis of daily time steps for five hydrological years (Oct. 1998-Sept. 2003). Model calculations were made for each of the 158 arable fields in the catchment, using field-specific soil, crop and management data of all the years as input. In order to reduce the importance of uncertain initial conditions, the model was run for a standard crop sequence and $\mathrm{N}$ fertilisation regime for each field during an eight-year warm-up period (Oct. 1990-Sept. 1998). Final values from the warm-up period were then used as initial values for the simulation period. Results at field level were areaweighted in order to provide aggregated mean values at the catchment level.

\subsubsection{Selection of model parameters}

The input parameter values required by the model were obtained from a combination of existing observations, available literature, expert judgment and calibration results.

As the parent model SOILN was shown to be particularly sensitive to $\mathrm{N}$ transformation parameters such as the potential nitrification rate and the C:N ratio of humus (Wu et al., 1998), we calibrated LEACHMN using a dataset from a long-term lysimeter experiment (Nievergelt, 2002). Except for the exclusive use of mineral fertilisers, the agro-pedoclimatic conditions in the lysimeter experiment reflected those of the Fehraltorf catchment. An inverse modelling method (Abbaspour et al., 2004) was used to achieve the closest match between simulated and observed values of $\mathrm{N}$ discharge over the period 1993-99, while ensuring that the estimated parameter values were in reasonable accord with literature sources: for a review of LEACHMN parameter values in the literature see Schmied et al. (2000). The results indicated that LEACHMN could satisfactorily predict the long-term average $\mathrm{N}$ discharge from the lysimeters, even though large discrepancies (up to $100 \%$ ) arose between simulations and observations in some years. Further detail is provided by Decrem et al. (2004). The calibrated parameter values are listed in Table II.

Potential evapotranspiration was calculated from the recorded climate data according to the Penman equation (Penman, 1948). A crop cover fraction was used to split potential evapotranspiration into potential evaporation and transpiration. An upper value for the crop cover fraction (0.73) was estimated by calibration.

Pedotransfer functions (Wösten et al., 1999) were used to derive soil hydrological parameters using textural information. A mean textural composition was estimated for each soil type using the soil data from VDZH (1998) collected at the level of Canton Zurich (Tab. I). To take into account the effect of the coarse material (particle diameter $>2 \mathrm{~mm}$ ) on the hydrological parameters, the volumetric water contents at wilting point, at field capacity, and at saturation were corrected, reducing them in proportion to the fraction of stone (Rawls et al., 1992). Across the different soil types, the available water content of a one-metre soil profile, calculated as the difference between volumetric water content at field capacity and wilting point, was generally close to $200 \mathrm{~mm}$ (Tab. I).

\subsubsection{Farm management data}

Since 1998, the farmers adhering to the scheme of the "Proof of ecological performance" have supplied management control sheets with field-specific information about cultivation practices, crops grown including yield levels, sowing and harvesting dates, and time and amount of fertiliser applied, including manure. Temporary grass-clover leys and silage maize were the predominant crops grown in the catchment, each covering c. $25 \%$ of the arable land area (Tab. III). A typical crop sequence was: silage maize, winter wheat, winter rape or winter barley, and 2 years of grass-clover ley (overwintering three times; sown after barley harvest and ploughed 
Table II. Values of $\mathrm{N}$ transformation parameters used in the LEACHMN simulations.

\begin{tabular}{|c|c|c|c|c|c|}
\hline \multirow[t]{2}{*}{ Parameter definition } & \multirow{2}{*}{$\begin{array}{l}\text { Symbol } \\
\text { (Johnsson et al., } \\
1987 \text { ) }\end{array}$} & \multirow[t]{2}{*}{ Unit } & \multirow[t]{2}{*}{ Value used } & \multicolumn{2}{|l|}{ Reference value } \\
\hline & & & & $\begin{array}{l}\text { Eckersten et al. } \\
\text { (1998) }\end{array}$ & $\begin{array}{l}\text { Schmied et al. } \\
\text { (2000) }\end{array}$ \\
\hline Partitioning coefficient of $\mathrm{NH}_{4}$ & - & $\mathrm{L} \mathrm{kg}^{-1}$ & 1.62 & - & $3.0 ; 4.0$ \\
\hline Synthesis efficiency factor & $f_{e}$ & - & 0.64 & $0.2-0.7$ & $0.48 ; 0.5$ \\
\hline Carbon humification fraction & $f_{h}$ & - & 0.63 & $0.1-0.9$ & $0.2 ; 0.52$ \\
\hline $\mathrm{C}: \mathrm{N}$ ratio of humus and microbial biomass & $r_{0}$ & - & 10.5 & $5-15$ & - \\
\hline Base temperature & $t_{b}$ & ${ }^{\circ} \mathrm{C}$ & 23.4 & 20 & - \\
\hline Response to a $10^{\circ} \mathrm{C}$ change & $Q_{10}$ & - & 1.54 & $1.5-4.0$ & $2.6 ; 3.0$ \\
\hline Higher end of optimum water content range & $\theta_{h o}$ & $\mathrm{~cm}^{3} \mathrm{~cm}^{-3}$ & 0.05 & $0.01-0.10$ & 0.08 \\
\hline Lower end of optimum water content range & $\theta_{l o}$ & $\mathrm{kPa}$ & -232 & - & -300 \\
\hline $\begin{array}{l}\text { Relative transformation rate at saturation } \\
\text { (except denitrification) }\end{array}$ & $e_{s}$ & - & 0.47 & $0-1$ & 0.6 \\
\hline Potential nitrification rate & $k_{n}$ & $\mathrm{~d}^{-1}$ & 0.20 & 0.2 & $0.02 ; 0.5$ \\
\hline Potential denitrification rate for layer $[0-30 \mathrm{~cm}]$ & $k_{d}$ & $\mathrm{~g} \mathrm{~N} \mathrm{~m}^{-2} \mathrm{~d}^{-1}$ & 0.026 & $0.04-0.2$ & $0.01 ; 0.75$ \\
\hline Potential mineralisation rate of crop residues & $k_{l}$ & $\mathrm{~d}^{-1}$ & 0.039 & 0.035 & $0.01 ; 0.19$ \\
\hline Potential mineralisation rate of humus & $k_{h}$ & $\mathrm{~d}^{-1}$ & $8.0 \times 10^{-5}$ & $1.0 \times 10^{-5}-20 \times 10^{-5}$ & $\begin{array}{l}1.7 \times 10^{-6} \\
7.0 \times 10^{-4}\end{array}$ \\
\hline Denitrification half saturation constant & $c_{s}$ & $\mathrm{mg} \mathrm{N} \mathrm{L}^{-1}$ & 8.9 & $5-15$ & - \\
\hline $\begin{array}{l}\text { Limiting } \mathrm{NO}_{3} / \mathrm{NH}_{4} \text { ratio in solution for } \\
\text { nitrification }\end{array}$ & $n_{q}$ & - & 10.0 & $1-15$ & - \\
\hline
\end{tabular}

Table III. Average areal fraction of the crops in the arable land of the Fehraltorf catchment, for the period 1998-2003; average national crop yields for the period prior to "Proof of ecological performance" (pre-PEP) and the contemporary period (1998-2002), and scaling coefficients used in the LEACHMN simulations.

\begin{tabular}{|c|c|c|c|c|}
\hline & \multirow{2}{*}{$\begin{array}{l}\text { Fraction of the total } \\
\text { arable area in the } \\
\text { catchment } \\
(\%)\end{array}$} & \multicolumn{2}{|c|}{ Average national yield $\left(\mathrm{kg} \mathrm{ha}^{-1}\right)^{1}$} & \multirow[b]{2}{*}{$\begin{array}{l}\text { Scaling coefficien } \\
\beta^{2}\end{array}$} \\
\hline & & $\begin{array}{l}\text { Pre-PEP period } \\
1989-1993\end{array}$ & $\begin{array}{l}\text { Period of } \\
\text { 1998-2002 }\end{array}$ & \\
\hline Silage maize & 22.8 & 17790 & 16500 & 1.08 \\
\hline Grain maize & 2.4 & 8500 & 9180 & 0.93 \\
\hline Spring barley & 0.1 & 4910 & 5170 & 0.95 \\
\hline Spring oats & 0.3 & 5190 & 5180 & 1.00 \\
\hline Spring wheat & 0.7 & 5320 & 4890 & 1.09 \\
\hline Triticale & 5.6 & 5520 & 6040 & 0.91 \\
\hline Winter barley & 9.8 & 6120 & 6040 & 1.01 \\
\hline Winter rape & 8.7 & 2820 & 3010 & 0.94 \\
\hline Winter rye & 0.5 & 5400 & 6110 & 0.88 \\
\hline Winter wheat & 18.5 & 5960 & 5830 & 1.02 \\
\hline Potatoes & 1.4 & 41670 & 38920 & 1.07 \\
\hline Sugar beets & 1.4 & 65860 & 69590 & 0.95 \\
\hline Sunflowers & 0.1 & N/A & 2950 & 1.00 \\
\hline Temporary leys & 26.7 & N/A & N/A & 1.00 \\
\hline
\end{tabular}

${ }^{1} \mathrm{~N} / \mathrm{A}$ : not available.

${ }^{2}$ If national yield statistics are not available, the standard value of 1.00 is utilised.

down just before sowing of maize). Catch crops were cultivated before spring-sown crops in the majority of cases. Overwintering grass-clover mixtures were chosen in preference to other catch crops, such as phacelia, because of their ability to produce fodder. Mouldboard ploughing was the most common method of tillage. Fertilisation was rather intensive and consisted of applied cow and pig manures and mineral fertiliser. The 1998-2003 average of the gross amount of min- eral fertiliser $\mathrm{N}$ and total $\mathrm{N}$ in livestock manure applied on the arable land in the catchment was $182 \mathrm{~kg} \mathrm{~N} \mathrm{ha}^{-1}$ year $^{-1}$, among which c. $60 \%$ represented manure N. Expressed as mineral N (sum of mineral fertiliser $\mathrm{N}$ and $\mathrm{NH}_{4}-\mathrm{N}$ in livestock manure), $116 \mathrm{~kg} \mathrm{~N} \mathrm{ha}^{-1}$ year $^{-1}$ were applied.

Missing yield values in the farmers' management control sheets were replaced using the corresponding catchment, canton Zurich, nationwide average values in the year concerned 
Table IV. Relative levels for the application of mineral and organic N fertilisers, crop yields and area cultivated with catch crops, simulated in the different scenarios.

\begin{tabular}{|c|c|c|c|c|}
\hline Scenario & $\begin{array}{l}\text { Amount of mineral } \mathrm{N} \\
\text { fertiliser applied }\end{array}$ & $\begin{array}{c}\text { Amount of organic } \mathrm{N} \\
\text { fertiliser applied }\end{array}$ & $\begin{array}{r}\text { Area cultivated } \\
\text { with catch crops }\end{array}$ & $\begin{array}{r}\text { Crop yield at } \\
\text { harvest }^{1}\end{array}$ \\
\hline (i) N PEP/CC PEP & $100 \%$ & $100 \%$ & $100 \%$ & $100 \%$ \\
\hline (ii) $\mathrm{N}$ unlimited/CC PEP & $128 \%$ & $126 \%$ & $100 \%$ & $88-109 \%$ \\
\hline (iii) $\mathrm{N}$ unlimited/CC $50 \%$ & $128 \%$ & $126 \%$ & $50 \%$ & $88-109 \%$ \\
\hline (iv) $\mathrm{N}$ unlimited/CC $0 \%$ & $128 \%$ & $126 \%$ & $0 \%$ & $88-109 \%$ \\
\hline
\end{tabular}

${ }^{1}$ Crop-specific scaling coefficients are indicated in Table III.

or standard yields (Walther et al., 2001) (in decreasing order of preference). The latter was systematically the case with ley. The distribution for the source of the yield data is as follows (for all arable crops except ley): farmers' own records 24\%; catchment average 29\%; Canton Zurich average 15\%; nationwide average $25 \%$; standard yields $7 \%$. Target crop N uptakes and $\mathrm{N}$ removed as main and by-product at harvest were calculated from the values of harvest yield, using standard plant $\mathrm{N}$ concentration data (Walther et al., 2001) and residue N/plant $\mathrm{N}$ ratios from the literature (e.g. Johnsson et al., 2002). Other crop-specific input parameters governing crop $\mathrm{N}$ (and water) uptake, such as potential rooting depth and maturity dates for root and cover, were derived from expert knowledge and literature sources.

When indications about $\mathrm{N}$ fertilisation in the farmers' control sheets were incomplete, they were complemented by data from Walther et al. (2001). The mineral fertiliser equivalent of manures was calculated using standard compositions (total N, plant-available N, ammonium N; Walther et al., 2001). For slurries, a standard dilution rate of 1:2 (one part slurry to two parts water) was assumed. The volatilisation subroutine of LEACHMN was not used. Instead, ammonia losses by volatilisation were calculated as a fraction of the applied amount of ammonium, using standard emission factors for the different types of organic and mineral fertilisers (Menzi et al., 1997). The ammonia emission factors were kept constant across the different scenarios.

For temporary grassland (grass-clover leys and grassclover catch crops), we assumed intensive management conditions, i.e. five cuttings a year, scheduled every month from May to September, a standard $\mathrm{N}$ fertiliser application of $150 \mathrm{~kg} \mathrm{~N} \mathrm{ha}^{-1}$ year $^{-1}$ (fractionated into five equal portions, applied after the cuttings), and a standard $\mathrm{N}$ uptake of $330 \mathrm{~kg} \mathrm{~N} \mathrm{ha}^{-1}$ year $^{-1}$, in accordance with statistical data (USP, 2004). Symbiotically-fixed $\mathrm{N}$ was estimated at $140 \mathrm{~kg} \mathrm{~N} \mathrm{ha}^{-1}$ year $^{-1}$ (Boller et al., 2003). The target net $\mathrm{N}$ uptake used in the simulations was defined as the difference between the total $\mathrm{N}$ uptake of the crop and the estimated fixed $\mathrm{N}$ and amounted to $190 \mathrm{~kg} \mathrm{~N} \mathrm{ha}^{-1} \mathrm{year}^{-1}$. In the case of grassclover catch crops, the target net $\mathrm{N}$ uptake was derived from Lehmann et al. (1991).

\subsubsection{Scenario concepts}

Four scenarios were established in order to investigate the effects of the $\mathrm{N}$ leaching reduction measures; namely, re- duced $\mathrm{N}$ fertilisation and increased use of catch crops (CC), in the Fehraltorf catchment (Tab. IV). In the first scenario "N PEP/CC PEP", LEACHMN was applied to the observed pedo-climatic and management conditions under the "Proof of ecological performance" programme between 1998 and 2003. Catch crop use during winter was assumed to be equivalent to the maximum feasible area. This scenario was considered as the reference level for evaluating the effectiveness of the $\mathrm{N}$ leaching reduction measures. Scenarios (ii), (iii) and (iv) represent scenarios prior to "Proof of ecological performance" (pre-PEP) with different levels of PEP rule application. Mineral and organic $\mathrm{N}$ fertiliser application and catch crop use were the variables used in the scenario analysis (Tab. IV). All other factors (pedo-climatic conditions, land use, crop sequence and distribution, organic fertiliser composition, atmospheric deposition and ammonia emission rates from fertiliser application) remained constant, with the actual conditions between 1998 and 2003 serving as the basis of reference.

The application rates of mineral and organic fertilisers, and crop yields used in the pre-PEP scenarios were determined on the basis of statistical information, mainly the annual statistics published by USP (2004) and OFS (2004). For each of the variables of interest, we calculated the ratios of the pre-PEP average to the contemporary average, either at the regional level (bordering municipalities, Canton Zurich) or at the national level, depending on the availability of statistical data. We used these ratios as scaling coefficients to derive, at the parcel level, the historical data from the data of "N PEP/CC PEP". This is expressed in the following equations:

$$
X(\text { pre-PEP })=\beta \mathrm{X}(\mathrm{N} \mathrm{PEP} / \mathrm{CC} \mathrm{PEP})
$$

where $X$ is the variable of interest (livestock manure application; mineral $\mathrm{N}$ fertiliser application; crop yield) on the field scale in a given scenario; $\beta$ is the scaling coefficient.

$$
\beta=\bar{X}(\text { pre-PEP }) / \bar{X}(\mathrm{~N} \text { PEP } / \text { CC PEP })
$$

where $\bar{X}$ is the average value of the variable of interest on the regional (neighbouring municipalities, canton) or national scale, for a given time period. The resulting crop-specific scaling factors are listed in Table III.

Catch crop use in the different scenarios was estimated, in the absence of accurate information from farmers' records and other sources. In "N PEP/CC PEP", use of catch crops on the maximum feasible area was hypothesised under the assumption of a full and thorough implementation of soil coverage 
as an ecological measure. This assumption may not accurately reflect actual site-specific conditions; as a result, soil coverage in "N PEP/CC PEP" may be overestimated to some extent. The relative use factor for catch crops in the pre-PEP scenarios was chosen to span the whole range of possibilities, from $0 \%$ to $100 \%$ with respect to "N PEP/CC PEP". The pre-PEP situation was assumed to be best described by the relative use factor of $50 \%$ in "N unlimited/CC 50\%". The relative use factor of $0 \%$ in "N unlimited/CC $0 \%$ " was purely hypothetical and had no other objective than to provide an estimate of the maximum reduction in mean $\mathrm{N}$ leaching achievable through the full implementation of soil coverage as an ecological measure.

\section{RESULTS AND DISCUSSION}

\subsection{Crop yields and simulated nitrogen uptake values}

National statistics indicate that crop yields of the pre-PEP period do not differ greatly from those of the contemporary period (USP 2004, Tab. III), in spite of the overall higher $\mathrm{N}$ fertiliser application rates used in the past. This can probably be explained by an adoption of more advanced technologies, including the use of new higher-yielding crop varieties, and a more efficient application of livestock manure as fertiliser. We also presume that there was excess fertilisation with nitrogen in the past, which has been reduced through the restrictions of the "Proof of ecological performance". There is no data or hard evidence, however, to test the validity of the two hypotheses.

The $9 \%$ increase in the average crop $\mathrm{N}$ uptake from " $\mathrm{N}$ $\mathrm{PEP} / \mathrm{CC}$ PEP" to "N unlimited/CC PEP" is somewhat greater than expected, given the assumption of little change in the arable crop productivity between the pre-PEP and contemporary period. The rationale is that in the LEACHMN simulations some of the target $\mathrm{N}$ uptakes in "N PEP/CC PEP" were too high compared with the amount of mineral $\mathrm{N}$ available in the root zone, and thus were not fulfilled. By contrast, all the target $\mathrm{N}$ uptakes were reached in "N unlimited/CC PEP", thanks to the increased $\mathrm{N}$ fertiliser application rates.

\subsection{Simulated percolation and $\mathbf{N}$ leaching values}

The catchment-averaged simulated percolation was $720 \mathrm{~mm}$ per year and ranged between $531 \mathrm{~mm}$ (dry year of 2002/03) and $957 \mathrm{~mm}$ (wet year of 1998/99). Percolation remained relatively constant across scenarios.

Simulated N leaching values differed considerably among fields within scenarios (Fig. 2). In the reference scenario "N $\mathrm{PEP} / \mathrm{CC}$ PEP", the mean leaching at field level ranged from 10 to $160 \mathrm{~kg} \mathrm{~N} \mathrm{ha}^{-1}$ year $^{-1}$. However, in $95 \%$ of cases, the mean leaching was between 15 and $70 \mathrm{~kg} \mathrm{~N}^{-1}$ year $^{-1}$. This rather moderate variation can be attributed to the fact that soil type and crop management were relatively homogenous throughout the catchment. The median value was around $30 \mathrm{~kg} \mathrm{~N} \mathrm{ha}^{-1}$ year $^{-1}$, which is close to the long-term average of $\mathrm{N}$ leaching rates of arable crop rotations in the lysimeter experiment used for calibrating the model. This result also

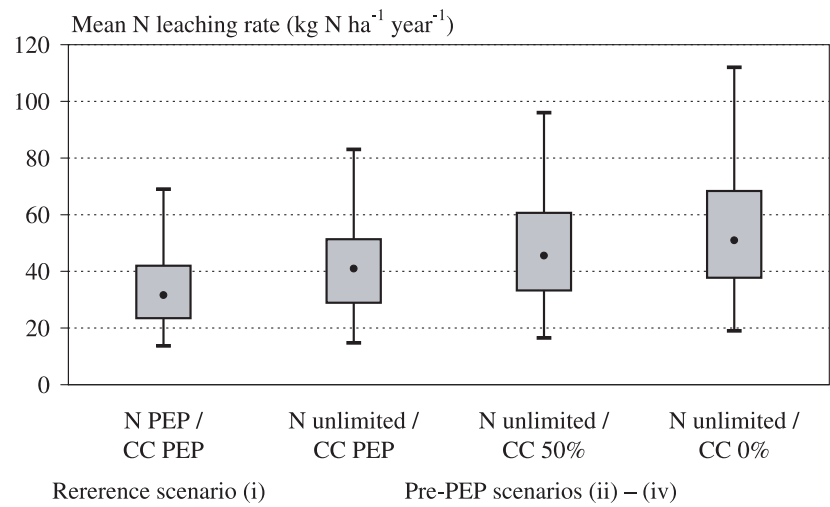

Figure 2. Figure 2: Box-plot of the frequency distribution of the simulated mean annual $\mathrm{N}$ leaching rates at field level, across the different scenarios. (The median for each dataset is indicated by the black centre dot, and the first and third quartiles are the edges of the grey area, representing the inter-quartile range. The upper and lower adjacent values, within 1.5 times the inter-quartile range from the upper or lower quartile, are the ends of the lines extending from the grey area. Outliers are omitted in the plot; PEP = Proof of ecological performance; $\mathrm{CC}=$ catch crop). See Table IV for scenario definitions.

agrees with $\mathrm{N}$ leaching estimates made by applying an empirical model on the scale of a bordering watershed (Prasuhn et al., 2004). The upper end of the distribution in Figure 2 corresponds to situations where $\mathrm{N}$ inputs via fertiliser application are high compared with $\mathrm{N}$ outputs via harvested products, either because of super-optimal fertilisation or crop failure. The ten or so outliers appearing for each of the scenario outcomes, with values from 69-157, 83-170, 96-186 and 112$218 \mathrm{~kg} \mathrm{~N} \mathrm{ha}^{-1}$ year $^{-1}$ for the four scenarios, respectively (not displayed in Fig. 2), corresponded to humus-rich, poorly drained gley soils, for which the application of the model may be questionable. Across the different scenarios, the average annual $\mathrm{N}$ leaching varied from a minimum of $39 \mathrm{~kg} \mathrm{~N} \mathrm{ha}^{-1}$ year $^{-1}$ for "N PEP/CC PEP" to a maximum of $59 \mathrm{~kg} \mathrm{~N}$ ha $^{-1}$ year $^{-1}$ for "N unlimited/CC $0 \% "$ (Tab. V). Within a scenario, the inter-annual variability of $\mathrm{N}$ leaching was notable (variation coefficient of c. $30 \%$ ). The difference between total $\mathrm{N}$ inputs and outputs per year was either close to zero ("N PEP/CC PEP") or slightly positive (the three pre-PEP scenarios), which indicates that the average $\mathrm{N}$ content of the root zone remained constant or increased slightly over time, mainly in the form of organic $\mathrm{N}$ bound in humus (Tab. VI).

\subsection{Effectiveness of the policy measures to reduce nitrogen leaching}

\subsubsection{Nitrogen fertilisation}

Comparing "N unlimited/CC PEP" with the reference scenario "N PEP/CC PEP" showed that the reduction in mineral $\mathrm{N}$ fertiliser and manure application yields a decrease in the mean $\mathrm{N}$ leaching of c. $10 \mathrm{~kg} \mathrm{~N} \mathrm{ha}^{-1}$ year $^{-1}$ (from 49 to $39 \mathrm{~kg} \mathrm{~N}^{-1}$ year $^{-1}$; Tab. VI), which corresponds to 
Table V. Simulated N leaching from the root zone in the Fehraltorf catchment. Values are indicated, on the basis of hydrological years, as catchment-averaged values $\left(\mathrm{kg} \mathrm{N}^{-1}\right.$ year $\left.^{-1}\right)$. PEP $=$ Proof of ecological performance; $\mathrm{CC}=$ catch crop. See Table IV for scenario definitions.

\begin{tabular}{lcccc}
\hline & $\begin{array}{c}\text { Reference scenario } \\
\text { (i) }\end{array}$ & $\begin{array}{c}\text { Pre-PEP scenarios } \\
\text { (iii) }\end{array}$ & (ii) \\
Hydrological year & N PEP/CC PEP & N unlimited/CC PEP & N unlimited/CC 50\% & N unlimited/CC 0\% \\
\hline Oct. 1998-Sept. 1999 & 57.2 & 70.8 & 79.6 & 85.6 \\
Oct. 1999-Sept. 2000 & 34.3 & 42.8 & 47.4 & 50.9 \\
Oct. 2000-Sept. 2001 & 46.9 & 59.0 & 4.2 & 71.1 \\
Oct. 2001-Sept. 2002 & 33.8 & 43.8 & 38.6 & 53.4 \\
Oct. 2002-Sept. 2003 & 22.6 & 28.0 & 32.7 & 35.5 \\
Mean & 38.9 & 48.9 & 17.9 & 59.3 \\
Std. deviation & 13.3 & 16.4 & $33 \%$ & 19.4 \\
Coefficient of variation & $34 \%$ & $34 \%$ & & $33 \%$ \\
\hline
\end{tabular}

Table VI. Simulated N mass balance in the root zone of the Fehraltorf catchment for the different scenarios, with catchment- and time-averaged annual values $\left(\mathrm{kg} \mathrm{N} \mathrm{ha}^{-1}\right.$ year $\left.^{-1}\right)$. For $\mathrm{N}$ inputs and outputs, relative differences with respect to Baseline are presented in brackets $(\%)$. PEP $=$ Proof of ecological performance; $\mathrm{CC}=$ catch crop. See Table IV for scenario definitions.

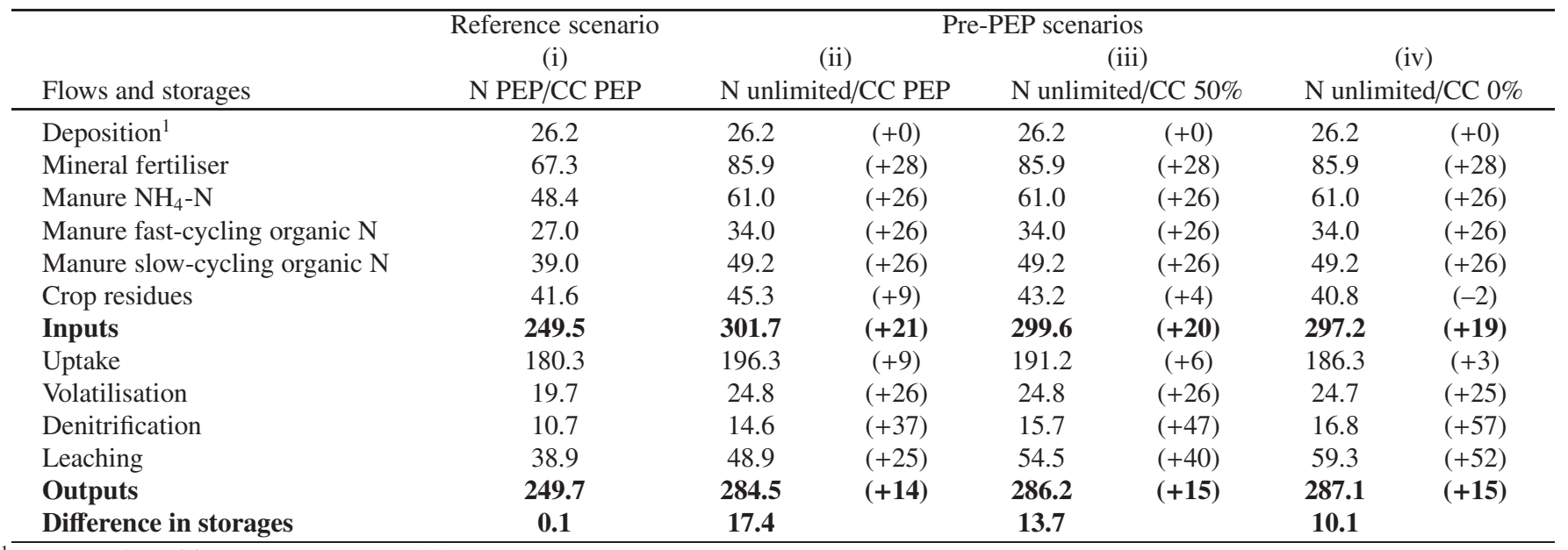

1 Average deposition rates, BUWAL (2002).

$6 \mathrm{mg} \mathrm{L}^{-1} \mathrm{NO}_{3}$ in the percolating water. This reduction in nitrate leaching of $20 \%$ is of a similar order of magnitude to reductions observed in other studies which investigated the effect of $\mathrm{N}$ leaching mitigation measures. Regardless of the $\mathrm{N}$ source (manure or mineral $\mathrm{N}$ fertiliser), super-optimal $\mathrm{N}$ fertilisation can increase the potential for nitrate leaching (Bergström and Brink, 1986). As a consequence, reducing the $\mathrm{N}$ fertilisation to optimal or slightly sub-optimal levels may decrease N leaching losses. Granlund et al. (2000) and MüllerWohlfeil et al. (2002) found a maximum reduction of $14 \%$ and $8 \%$, respectively, for study areas in Finland and Denmark, but the reduction in $\mathrm{N}$ fertiliser use in these areas was lower than in our study.

\subsubsection{Catch crops}

The quantitative comparison between " $\mathrm{N}$ unlimited/CC $50 \%$ " and "N unlimited/CC PEP" revealed that increasing the use of catch crops leads to a decrease in the mean $\mathrm{N}$ leaching of c. $5 \mathrm{~kg} \mathrm{~N} \mathrm{ha}^{-1}$ year $^{-1}$ (from 54 to $49 \mathrm{~kg} \mathrm{~N}$ ha $^{-1}$ year $^{-1}$;
Tab. VI), corresponding to $3.4 \mathrm{mg} \mathrm{\textrm {L } ^ { - 1 }} \mathrm{NO}_{3}$. The comparison of the results for "N unlimited/CC $0 \%$ " with those for "N unlimited/CC PEP" indicated the maximum reduction in mean $\mathrm{N}$ leaching achievable through the use of catch crops, with $\mathrm{N}$ fertiliser application rates remaining the same: $\mathrm{c}$. $10 \mathrm{~kg} \mathrm{~N} \mathrm{ha}^{-1}$ year $^{-1}$ (from 59 to $49 \mathrm{~kg} \mathrm{~N} \mathrm{ha}^{-1}$ year $^{-1}$ ).

The establishment of catch crops in late summer after the harvest of preceding crops is an effective way of reducing nitrate leaching because they can take up significant amounts of $\mathrm{N}$ before the winter leaching period (Dabney et al., 2001). Catch crops may reduce $\mathrm{N}$ leaching losses by 26 up to $70 \%$ depending on the type of catch crop and on its position in the crop rotation (Aronsson and Torstensson, 1998; Beaudoin et al., 2004; Askegaard et al., 2005; Tonitto et al., 2006). In our study, the mean simulated reduction in $\mathrm{N}$ leaching on arable fields between "N unlimited/CC 50\%" and "N unlimited/CC PEP" by doubling of catch cropping was $11 \%$. This corresponds to a reduction of $22 \%$ on fields with catch crop cultivation, as the mean catch crop use was $50 \%$ of maximal potential catch cropping. The fact that the simulated effect of catch crops on nitrate leaching in our study is somewhat smaller than in the 


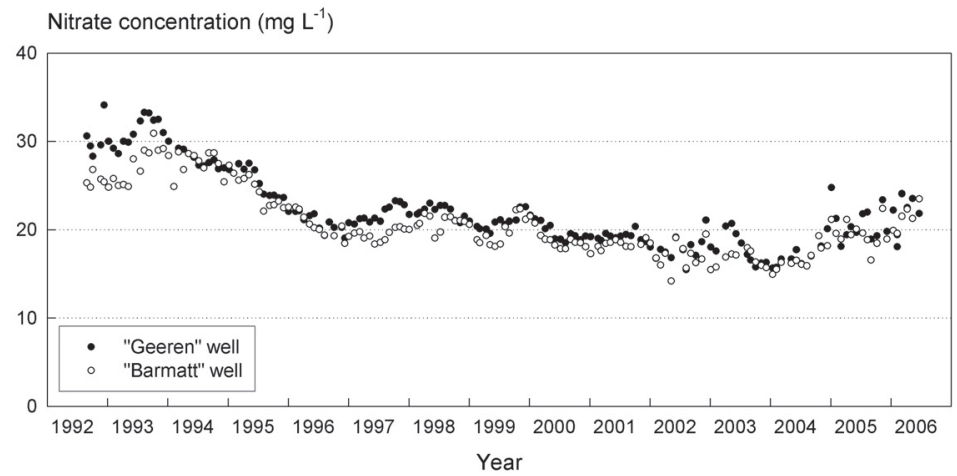

Figure 3. Temporal development of nitrate concentrations of drinking water from two municipal wells in the Fehraltorf catchment.

references cited above may have different reasons. First, the pre-PEP levels of nitrogen fertilisation were relatively moderate compared with $\mathrm{N}$ fertilisation intensities in more intensive arable production systems. Thus, residual contents of soil mineral $\mathrm{N}$, which mainly determine the $\mathrm{N}$ leaching potential, are assumed to be comparatively low in our study area. Secondly, reported reductions in $\mathrm{N}$ leaching by catch crops are usually greater on sandy soils (Lewan, 1994; Beaudoin et al., 2005), not present in our study catchment.

\subsubsection{Combined effects of nitrogen fertilisation and catch crops}

On the whole, the combined effect of the implemented policy measures in our study was estimated to amount to a reduction in the mean $\mathrm{N}$ leaching of c. $16 \mathrm{~kg} \mathrm{~N}^{-1}$ year $^{-1}$, corresponding to $29 \%$ or $9.4 \mathrm{mg} \mathrm{L}^{-1} \mathrm{NO}_{3}$.

Hoffmann and Johnsson (2004) predicted for agricultural land in southern Sweden a decrease in leaching of $16 \%$ after introducing catch crops, reducing $\mathrm{N}$ fertilisation by c. $10 \%$, and application of animal manure only in spring. Børgensen et al. (2001) calculated for Denmark a reduction in nitrate leaching of $35 \%$ between 1985 and 1994. Policy measures implemented in this period involved a higher percentage of winter crops and crops harvested in late autumn, the limitation of the manure application period to spring only, and a reassessment of the guidelines for the $\mathrm{N}$ fertilisation potential of slurry (assuming higher mineral fertiliser equivalents).

\subsection{Plausibility of model predictions}

Ideally, modelling data is validated against measured values. This is problematic, however, at the catchment level. Because of the lack of information concerning residence time, flow patterns and potential for denitrification of the Fehraltorf groundwater, and, on the other hand, the inputs of $\mathrm{N}$ to the groundwater other than from arable land (permanent grassland, forest and point sources of pollutants such as sewage leaks), we cannot directly corroborate our simulations against the reported decrease in groundwater nitrate concentration in the catchment (Fig. 3). However, the observed trend in groundwater $\mathrm{N}$ concentration agrees qualitatively with the reduction in $\mathrm{N}$ leaching predicted in the simulations.

At the beginning of the 1990s, the Fehraltorf catchment was considered a problematic area, with groundwater nitrate concentration in two municipal drinking water wells lying between 25 and $35 \mathrm{mg} \mathrm{L}^{-1}$. Since the introduction of direct payments bound to ecological measures in 1993, nitrate concentration in the groundwater has dropped to around 15$20 \mathrm{mg} \mathrm{L}^{-1}$ (Fig. 3). The period around 1993 also saw the start of a major overhaul of the sewer and storm drain system in the municipalities bordering on the catchment (Krejci et al., 1994), which - in addition to agricultural policy measures may also have contributed to the improvement in groundwater quality. Since 2004, nitrate contents have been rising, presumably due to adverse climatic conditions (e.g. nitrate accumulation during the dry summer of 2003) and decreasing cover cropping as a result of lowering the requirements of the "Proof of ecological performance" in 2004.

Because the model cannot be properly validated on the catchment scale, it is important to address the different possible sources of uncertainty in the model predictions.

- Inaccuracies in the determination of soil hydrological parameters that significantly affect the soil water regime may originate either from non-representative mean textural compositions derived from the Canton Zurich soil survey database or by errors introduced by use of the pedotransfer functions.

- Crop $\mathrm{N}$ uptake, which constitutes the main $\mathrm{N}$ flux in the system, was determined from crop yields and standard crop $\mathrm{N}$ concentrations. This simple approach ignores the variability in crop $\mathrm{N}$ concentrations. Moreover, to handle the problem of missing yield data, catchment, region or nationwide average yields, if not standard yields were used. On the whole, less than $15 \%$ of the yield values used in the simulations correspond to field-specific values from the farmers' records. To what extent the substitute data values are representative is unknown.

- The large natural variability in the composition of livestock manure, especially slurry, was not taken into account in the simulations. Instead, standard values for $\mathrm{N}$ content and dilution of slurry with water were used. As 
livestock manure is a substantial source of $\mathrm{N}$ in the catchment, this introduces a considerable source of uncertainty in the model predictions.

As we do not know the uncertainty in agricultural management data, which is probably the main source of uncertainty of the simulated $\mathrm{N}$ leaching rates, the model's predictive uncertainty is unknown. Our main interest, however, lies in the relative differences between scenario predictions and a possible systematic bias, therefore, is less relevant. Therefore, even if differences between scenarios are significantly smaller than the uncertainty in the scenario predictions themselves, scenario studies still provide useful and relevant information (Reichert and Borsuk, 2005). They may at least reveal that the studied policy measures led to changes in the desired direction.

\section{CONCLUSION}

Agri-environmental measures can be regarded as "real world experiences" which are initiated by policy-makers and carried out by farmers. In scientific experiments, a maximum of factors is controlled but this is not the case in agrienvironmental measures. Many factors such as weather conditions, technical progress and market developments, which determine the choice of crops, the intensity of crop production and the type and intensity of animal husbandry, also affect the parameters to be measured $-\mathrm{N}$ leaching in this case. The application of LEACHMN in four policy scenarios allowed the study of the effect of balanced farm $\mathrm{N}$ budgets and of catch crop planting independently from the other factors acting on $\mathrm{N}$ leaching. We were able to demonstrate that the implementation of reduced $\mathrm{N}$ fertiliser inputs and increased use of catch crops led to a substantial mean reduction in $\mathrm{N}$ leaching of $29 \%$ $\left(16 \mathrm{~kg} \mathrm{ha}^{-1}\right.$ year $\left.^{-1}\right)$ for arable land in the Fehraltorf catchment. Our results, indicating the efficacy of these agri-environmental measures, were communicated to the political authorities and were used in the formulation of the new policy project for the period 2008-11.

Our findings cannot be validated by field measurements, which are impossible to carry out on the catchment scale. The availability of farm management data was a major "bottleneck" for this modelling exercise and ways should be found (by extension and control agencies) to improve this information. This would strongly reduce the results' uncertainty. Taking into account the main sources of errors and uncertainty (e.g. quality of farm management data and accuracy of soil parameters), the reliability of the findings should be assessed in a next step. This will allow the policy-makers to be better informed about the potential of improved abatement strategies that are based upon a combination of different countermeasures.

Acknowledgements: We would like to thank Karim Abbaspour and Peter Reichert, René Gämperle, Samuel Gerber, Olivier Huguenin, Reto Mani, Jakob Nievergelt, Martin Ramsauer, Ömer Resitoglu and Erich Szerencsits, who have given us inspiration, contributed information or helped us with critical comments. We also thank the farmers for the information they provided and three anonymous reviewers for their comments on a draft of the manuscript. Part of this study was funded by the Federal Office for the Environment and by the Federal Office for Agriculture.

\section{REFERENCES}

Abbaspour K.C., Johnson A., van Genuchten M.Th. (2004) Estimating uncertain flow and transport parameters using a sequential uncertainty fitting procedure, Vadose Zone J. 3, 1340-1352.

Addiscott T.M., Mirza N.A. (1998) Modelling contaminant transport at catchment or regional scale, Agr. Ecosyst. Environ. 67, 211-221.

Aronsson H., Torstensson G. (1998) Nitrogen leaching, nitrogen mineralisation and change in soil organic nitrogen in a field experiment with frequent use of catch crops, Soil Use Manage. 14, 6-13.

Askegaard M., Olesen J.E., Kristensen K. (2005) Nitrate leaching from organic arable crop rotations: effects of location, manure and catch crop, Soil Use Manage. 21, 181-188.

Beaudoin N., Mary B., Laurent F., Aubrion G., Saad J.K. (2004) Is the $\mathrm{N}$ balance a good indicator of nitrogen losses in arable systems? in: Hatch D.J., Chadwick D.R., Jarvis S.C., Roker J.A. (Eds.), Controlling nitrogen flows and losses, Proc. of the 12th Nitrogen Workshop, Wageningen Academic Publishers, Wageningen, pp. 487-489.

Beaudoin N., Saad J.K., van Laethem C., Machet J.M., Maucorps J., Mary B. (2005) Nitrate leaching in intensive agriculture in Northern France: Effect of farming practices, soils and crop rotations, Agr. Ecosyst. Environ. 111, 292-310.

Bergström L., Brink N. (1986) Effects of differentiated applications of fertilizer on leaching losses and distribution of inorganic $\mathrm{N}$ in the soil, Plant Soil 93, 333-345.

Boller B., Lüscher A., Zanetti S. (2003) Schätzung der biologischen Stickstoff-Fixierung in Klee-Gras-Beständen, Schriftenreihe der FAL 45, 47-54.

Børgesen C.D., Djurhuus J., Kyllingsbæk A. (2001) Estimating the effect of legislation on nitrogen leaching by upscaling field simulations, Ecol. Model. 136, 31-48.

BUWAL (2002) Stickstoff-Depositionskarte der Schweiz - Stand 1998. Bundesamt für Umwelt, Wald und Landschaft (BUWAL) $<$ http://stratus.meteotest.ch/lugis/map/presentation/lugis_style/ map.asp > . Last accessed February 2007.

BUWAL, BWG (2004) NAQUA - Grundwasserqualität in der Schweiz 2002/2003, Bundesamt für Umwelt, Wald und Landschaft / Bundesamt für Wasser und Geologie (Eds.), Bern, 204 p.

Chaplot V., Saleh A., Jaynes D.B., Arnold J. (2004) Predicting water, sediment and $\mathrm{NO}_{3}-\mathrm{N}$ loads under scenarios of land-use and management practices in a flat watershed, Water Air Soil Poll. 154, 271-293.

Conseil Fédéral (1998) Ordonnance des paiements directs, Berne, SR 910.13

Dabney S.M., Delgado J.A., Reeves D.W. (2001) Using winter cover crops to improve soil quality and water quality, Commun. Soil Sci. Plant Anal. 32, 1221-1250.

Decrem M., Abbaspour K.C., Nievergelt J., Herzog F., Richner W. (2004) Inverse stochastic modelling of water and $\mathrm{N}$ drainage from lysimeters, in: Hatch D.J., Chadwick D.R., Jarvis S.C., Roker J.A. (Eds.), Controlling nitrogen flows and losses, Proc. of the 12th Nitrogen Workshop. Wageningen Academic Publishers, Wageningen, pp. 417-418.

Eckersten H., Jansson P.E., Johnsson H. (1998) SOILN Model, Version 9.2, User's. Manual, Division of Agricultural Hydrotechnics, Communication 98(6). 
Fassio A., Giupponi C., Hiederer R., Simota C. (2005) A decision support tool for simulating the effects of alternative policies affecting water resources: an application at the European scale, J. Hydrol. 304, $462-476$.

Granlund K., Rekolainen S., Grönroos J., Nikander A., Laine, Y. (2000) Estimation of the impact of fertilisation rate on nitrate leaching in Finland using a mathematical simulation model, Agr. Ecosyst. Environ. 80, 1-13.

Herzog F. (2005) Agri-environmental schemes as landscape experiments, Agr. Ecosyst. Environ. 108, 175-177.

Herzog F., Richner W. (Eds.) (2005) Évaluation des mesures écologiques : Domaines de l'azote et du phosphore, Agroscope FAL Reckenholz, Zurich, Les cahiers de la FAL 57, 132 p.

Hoffmann M., Johnsson H. (2004) Nitrogen leaching from agricultural land in Sweden, Ambio 29, 67-73.

Hutson J.L. (2003) LEACHM - Model description and user's guide. School of Chemistry, Physics \& Earth Sciences, The Flinders University of South Australia, GPO Box 2100, Adelaide, SA5001. <www.scieng.flinders.edu.au/cpes/people/ hutson_j/leachweb.html>. Last accessed July 2005.

Hutson J.L., Wagenet R.J. (1991) Simulating nitrogen dynamics in soils using a deterministic model, Soil Use Manage. 7, 74-78.

Jabro J.D., Toth J.D., Dou Z., Fox R.H., Fritton D.D. (1995) Evaluation of nitrogen version of LEACHM for predicting nitrate leaching, Soil Sci. 160, 209-217.

Jemison J.M. Jr., Jabro J.D., Fox R.H. (1994) Evaluation of LEACHM II. Simulation of nitrate leaching from nitrogen-fertilized and manured corn, Agron. J. 86, 852-859.

Johnsson H., Bergström L., Jansson P.-E., Paustian K. (1987) Simulated nitrogen dynamics and losses in a layered agricultural soil, Agr. Ecosyst. Environ. 18, 333-356.

Johnsson H., Larsson M.H., Mårtensson K., Hoffmann M. (2002) SOILNDB: a decision support tool for assessing nitrogen leaching losses from arable land, Environ. Modell. Softw. 17, 505-517.

Krejci V., Fankhauser R., Gammeter S., Grottker M., Harmuth B., Merz P., Schilling W. (1994) Integrierte Siedlungsentwässerung, Fallstudie Fehraltorf, EAWAG Report, No. 8, Dübendorf, 268 p.

Lehmann J., Briner H.U., Rosenberg E. (1991) Zwischenkulturen - was können sie und was können sie nicht? Landwirtschaft Schweiz 4, $151-158$.

Lewan E. (1994) Effects of a catch crop on leaching of nitrogen from a sandy soil: simulations and measurements, Plant Soil 166, 137-152.

Menzi H., Frick R., Kaufmann R. (1997) Ammoniak-Emissionen in der Schweiz: Ausmass und technische Beurteilung des Reduktionspotentials, Schriftenreihe der FAL 26, 107 p.

Müller-Wohlfeil D.-I., Jørgensen J.O., Kronvang B., Wiggers L. (2002) Linked catchment and scenario analysis of nitrogen leaching and loading: a case study from a Danish catchment-fjord system, Mariager Fjord, Phys. Chem. Earth 27, 691-699.

Ng H.Y.F., Drury C.F., Serem V.K., Tan C.S., Gaynor J.D. (2000) Modeling and testing of the effect of tillage, cropping and water management practices on nitrate leaching in clay loam soil, Agr. Water Manage. 43, 111-131.

Nievergelt J. (2002) Nitrat und Fruchtfolgen 20 Jahre lang beobachtet, Agrarforschung 9, 28-33.

OFAG (2006) Rapport agricole, Federal Office for Agriculture (OFAG), Berne, $235 \mathrm{p}$.
OFS (2004) Agricultural statistics, Swiss Federal Statistical Office (OFS), Neuchâtel, 198 p.

Penman H.L. (1948) Natural evaporation from open water, bare soil and grass, Proc. R. Soc. A 193, 120-146.

Prasuhn V., Herzog F., Schärer M., Frossard E., Flühler H., Flury C., Zgraggen K. (2004) Stoffflüsse im Greifenseegebiet: Phosphor und Stickstoff, Agrarforschung 11, 440-445.

Prasuhn V., Sieber U. (2005) Changes in diffuse phosphorus and nitrogen inputs into surface waters in the Rhine watershed in Switzerland, Aquat. Sci. 67, 363-371.

Rawls W.J., Ahuja L.R., Brakensiek D.L., Shirmohammadi A. (1992) Infiltration and soil water movement, in: Maidment D.R. (Ed.), Handbook of Hydrology, McGraw-Hill, New York, pp. 5.1-5.51.

Reichert P., Borsuk M.E. (2005) Does high forecast uncertainty preclude effective decision support? Environ. Modell. Softw. 20, 991-1001.

Schmied B., Abbaspour K.C., Schulin R. (2000) Inverse estimation of parameters in a nitrogen model using field data, Soil Sci. Soc. Am. J. $64,533-542$.

Sogbedji J.M., van Es H.M., Hutson J.L. (2001a) N rate and transport under variable cropping history and fertiliser rate on loamy sand and clay loam soils: I. Calibration of the LEACHMN model, Plant Soil 229, 57-70.

Sogbedji J.M., van Es H.M., Hutson J.L. (2001b) N rate and transport under variable cropping history and fertiliser rate on loamy sand and clay loam soils: II. Validation of the LEACHMN model using different calibration scenarios, Plant Soil 229, 71-82.

Spiess E. (2005) Le bilan de l'azote en Suisse, in: Herzog F., Richner W. (Eds.), Évaluation des mesures écologiques : Domaines de l'azote et du phosphore, Agroscope FAL Reckenholz, Zurich, Les cahiers de la FAL 57, 26-31.

Tonitto C., David M.B., Drinkwater L.E. (2006) Replacing bare fallows with cover crops in fertilizer-intensive cropping systems: a metaanalysis of crop yield and N dynamics, Agr. Ecosyst. Environ. 112, $58-72$.

USP (2004) Statistiques et évaluations concernant l'agriculture et l'alimentation, Swiss Farmers' Union (USP), Brugg, 224 p.

VDZH (1998) Landwirtschaftliche Bodenkarte des Kantons Zürich 1:5'000, Fachstelle Bodenschutz, Amt für Landschaft und Natur, Volkswirtschaftsdirektion des Kantons Zürich (VDZH), Zürich.

Walther U., Ryser J.P., Flisch R. (2001) Grundlagen für die Düngung im Acker- und Futterbau 2001, Agrarforschung 8, supplement, 88 p.

Wendland F., Bach M., Kunkel R. (1998) The influence of nitrate reduction strategies on the temporal development of the nitrate pollution of soil and groundwater throughout Germany - a regionally differentiated case study, Nutr. Cycl. Agroecosys. 50, 167-179.

Wolf J., Oenema O., Rötter R.P. (2005) Nutrient emission models in environmental policy evaluation at different scales - experience from the Netherlands, Agr. Ecosyst. Environ. 105, 291-306.

Wösten J.H.M., Lilly A., Nemes A., Le Bas C. (1999) Development and use of a database of hydraulic properties of European soils, Geoderma 90, 169-185.

Wu L., McGechan M.B., Lewis D.R., Hooda P.S., Vinten A.J.A. (1998) Parameter selection and testing the soil nitrogen dynamics model SOILN, Soil Use Manage. 14, 170-181. 